\title{
Fiscaoeconomia
}

E-ISSN: 2564-7504

2021, Volume 5, Issue 2, 492-504

https://dergipark.org.tr/tr/pub/fsecon

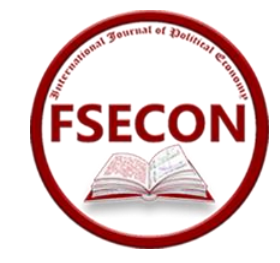

\section{Economic Effects of the First World War on Rize}

\section{Birinci Dünya Savaşı'nın Rize'ye Ekonomik Etkileri}

\section{Kamil Semih KALYONCUOĞLU ${ }^{1}$}

\begin{abstract}
One of the fronts that caused many economic and social problems for the Ottoman Empire during the First World War, in which the Ottoman Empire was a part, is the Caucasus Front. Shortly after the war started, the Russians attacked the Ottoman Empire from the Caucasus Front by sea and land, and the region was severely damaged. With the fall of the Caucasus Front, which had great hopes, the Russians started to bomb and capture the present Eastern Black Sea region, including Rize. Especially between 1916-1918, Rize, one of the important centers in the region, was badly affected economically by this war and the people of the region had to migrate to the west. In this study, the economic effects of the war on Rize were examined, and it was understood that Rize suffered severe damage both economically and socially.
\end{abstract}

Jel Codes: Z00, Z10, Z19

Keywords: World War I, Rize, Ottoman, Russia, Economy

\section{Öz}

Osmanlı Devleti'nin içinde yer aldığı Birinci Dünya Savaşı'nda, Osmanlı Devleti açısından ekonomik ve toplumsal birçok problemin doğmasına sebep olan cephelerden biri de Kafkasya Cephesidir. Savaşın başlamasından kısa bir süre sonra Ruslar, deniz ve kara yoluyla Kafkasya Cephesinden Osmanlı Devleti'ne taarruz etmiş ve bölge oldukça hasar görmüştür. Büyük umutlar bağlanan Kafkasya Cephesi'nin düşmesiyle Ruslar, Rize dahil olmak üzere bugünkü Doğu Karadeniz bölgesini bombalamaya ve ele geçirmeye başlamıştır. Özellikle 1916-1918 yılları arasında bölgede yer alan önemli merkezlerden biri olan Rize de bu savaştan ekonomik olarak oldukça kötü etkilenmiş ve bölge halkı batıya göç etmek zorunda kalmıştır. Bu çalışmada, savaşın Rize'ye ekonomik etkileri incelenmiş, Rize'nin hem ekonomik hem de toplumsal açıdan ağır zarara uğradığı anlaşılmıştır.

Jel Kodları: Z00, Z10, Z19

Anahtar Kelimeler: Birinci Dünya Savaşı, Rize, Osmanlı, Rusya, Ekonomi

\footnotetext{
${ }^{1}$ Research Assistant; Departman of Economics, İstanbul University, İstanbul, Turkey, semihkalyoncuoglu@istanbul.edu.tr, ORCID: 0000-0002-5139-1959
}

Citation/Atıf: Kalyoncuoğlu, K. S. (2021). Economic effects of the First World War on Rize. Fiscaoeconomia, 5(2), 492-504. doi: 10.25295/fsecon.899773 


\section{Introduction}

The First World War is one of the bloodiest wars that history has ever witnessed. This war started on 1 August 1914 and lasted about 4.5 years. The total population in the world was recorded as $1,175,400$ people at that time. Considering this population, the fact that the number of soldiers taken to war worldwide is approximately 61 million and approximately 8.5 million people lost their lives in the war reveals the burning and destructive effect of the First World War. In addition, 18.5 million people were injured, and 7 million people were captured. The expenditures made by the countries participating in the war were recorded as 186 billion dollars (Topaloğlu, 2007: p.15-16). Before entering the First World War, the Ottoman Empire followed various strategies to determine which side it would take place. The common point of these strategies is the hope of getting back as much as possible of the lands lost by the Ottoman State before the war. The Allied Powers led by Britain, France and Russia were on the one hand and the central powers led by Germany and Austria-Hungary on the other. The Ottoman State did not determine which side it would take place precisely and negotiated with both sides. At the same time Going to war alongside the Allied Powers would not have gained much for the Ottoman Empire. However, going to war on the side of Germany meant getting rid of capitulations, Düyun-u Umûmiyye ${ }^{2}$ and Russian attacks. On the other hand, it also meant compensating for the losses of the Balkan Wars (Aybars: 2000: p.47). Realizing that it could not get what it wanted from the Allied Powers, the Ottoman Empire decided to join the central powers. In this decision, the efforts of the Germans to attract the Ottoman Empire to their side seem very important. One of the most important roles of the Ottoman Empire, after collusion with the Germans in August 1914, was to win against the Russian forces in the east or to stand against them as a force to prevent them. In the period following the agreement in question, an important detail about the Ottoman Empire is that the Ottoman Empire felt compelled to go to war in Germany; but that he is not in a hurry for this, trying to delay it as much as possible. On the contrary, Germany wanted its ally to go to war as soon as possible (Alkan, 2014: p.161).

The Ottoman Empire's participation in the war was a very promising development for the Germans. The Ottoman Empire, which was in a very strategic position in order to prevent the Russians' policy of going down to the hot seas and capturing the straits, aimed to prevent the Russians by confronting them in the Black Sea. Because in the years of the war, the sea route was both safer and faster than the road. At the same time, in the seas, absolute superiority should be achieved, and the Russians should not be allowed to pass.

Participation in the allied and central blocks that formed when the war started had begun. Italy, which was previously in the block of the central powers, passed to the allies and after then important states such as the USA and Japan joined this bloc. Only Bulgaria joined the

\footnotetext{
${ }^{2}$ The Crimean War between the Ottomans and Russia shook the Ottoman Finance. The Ottoman State received its first foreign debt in 1854 to finance this war. Due to financial difficulties, Ottomans had to take on foreign debt 15 more times until 1874. As it was unable to pay the debts, the Ottoman Empire established Ottoman Public Debt Administration (OPDA)

which is known as Düyun-u Umûmiyye in Ottoman Turkish in order to pay its debts. See: Küçük, C. \& Ertüzün, T. (1994). "Düyûn-ı Umûmiyye", TDV íslam Ansiklopedisi içinde (Cilt 10, 58-62.) İstanbul: TDV İslâm Araştırmaları Merkezi.
} 
central powers' bloc. In such an environment where the balance of power deteriorated, the situation became more complicated for the Ottoman Empire, which could not overcome the economic and military problems of the Balkan Wars. The insufficient ammunition and military force of the Ottoman Empire were highly divided as a result of the increase in the number of fronts and the number of soldiers fighting on the fronts. It was inevitable that the troops would be divided into different fronts and therefore the fronts would become more vulnerable. It is seen that this troubled situation is also valid for the Caucasus Front, which has great hopes.

When the events in Rize are examined in particular, Russia's desire to have Trabzon, which has followed an expansionist policy since the 18th century, seems possible with the capture of Rize. As it is known, Trabzon is an important trade center. In addition to having a highcapacity port, Trabzon has increased its trade volume with the road to Iran and has become one of the busiest points in the region. For these reasons, Trabzon and its surroundings have become one of the important points to capture. The beginning of the First World War meant the implementation of this policy of Russia and Russia took action without wasting time. One of the important stops of this movement is the Sanjak of Lazistan and Rize which is the center of banner. The First World War seems to have worn the region materially and morally, and Rize in particular. When the economic life before and after the war is examined, this situation becomes clear. In addition to all these, the people of the region had to migrate due to the extraordinary situation brought by the war conditions. The immigration life seems to have begun for the people of the region who came to the West and high places. This situation leads to the conclusion that war also has psychological effects. It has been concluded that the people of the region are not only affected economically and sociologically, but also psychologically worn out.

\section{War Economy Politics: Ottoman Empire during the First World War}

Before the First World War, it is striking that the Ottoman Empire was in a very troubled financial situation. Because many wars were fought before, such as the Balkan Wars, and even the financial crises caused by these wars were not overcome yet. The transfer of economic resources to military equipment and army supplies due to wars made the financial situation even more depressed. At this point, it will be useful to examine the Ottoman war economy that we come across.

War economy, in general terms, means that a state devotes all its resources to the production of war equipment and the supply of the army to fight (Müderrisoğlu, 1990: p.287). The state aims to transfer its resources to areas that can be considered as a basic need for war, to get out of the war successfully and to protect its future. States have resorted to various monetary policies to sustain a difficult economy in times of war. One of the policies followed by the Ottoman Empire in these periods is adultery policy.

According to Şevket Pamuk, the first important adulteration was made in 1585. Although adultery seems beneficial in the short term in cases such as paying the state's debt and military salaries, it causes the purchasing power of the reaper to decrease and the prices to increase in the long term. For this reason, the year 1585 emerges as the clearest example of the loss of power of the Ottoman Finance. After this date, it was understood that the land and tax system had to change, and different taxation methods were tried. However, the abandonment of the 
Kalyoncuoğlu, K. S. (2021). Economic effects of the First World War on Rize.

Fiscaoeconomia, 5(2), 492-504. doi: 10.25295/fsecon.899773

fief and the trial of the tax farming, then the mansion, and finally the esham system could not solve the financial crisis. During the period of peace in the 18th century, the Ottoman finance recovered, but later long-term wars and the high costs of these wars caused the financial system to weaken again. In the 19th century, the tax revenues of the Ottoman Empire, which strengthened its centralist position, increased, but the wars and the success of the West in the production of manufactured goods prevented the Ottoman Empire from reaching the desired level both economically and financially (2005: p.113-130).

The Ottoman State established the land system and tax system to meet its military needs. The finance regulated by the taxes to be obtained from the lands and lands was built on the funding of the military institution. To summarize, the land system and the financial and military structure have been formed in a way that feeds each other (Özvar, 2003: p.10-11). Many measures had to be taken by the Ottoman administration, as the central army gained importance, the expeditions took longer and therefore the need for cash increased. Examples of these measures include reducing military spending and the number of soldiers, deferring treasury debts, imposing new taxes and raising existing taxes, especially when there is no war. Taxes such as imdad-ı seferiyye, bedel-i tımar, which can be considered as new, were taken on the grounds of meeting the needs of the treasury, especially in times of war (Tabakoğlu, 1985: p.257-298).

Before the First World War, the Ottoman empire was not ready for a prolonged war. Internal resources were insufficient to finance the war; Therefore, a large amount of borrowing was made. The economy of the country is not enough to meet the needs of manpower, industry, agriculture, foreign debts, transportation and national production (Coşkun, 2003: p.72).

The distinctive features of the Ottoman economy in the First World War are an underdeveloped economy and a state with limited administrative capacity. Both agriculture and industrial production decreased significantly in the face of the pressures created by the war. Despite this, he had to fight on many fronts. The Ottomans managed to survive in the war and on most fronts until the end of 1918. Looking at the previous year in 1914, the average increase in agriculture is around $13 \%$. Decreases in products were seen only in olives and tobacco, which indicates that the state entered the war with sufficient food stocks. By 1915, 4 million decares of wheat cultivation and $30 \%$ decrease in crops occurred, so the food problem in provinces and cities reached its peak (Eldem, 1994: p.34). Various measures have been taken due to the insufficient economic conditions of the country. During the First World War, the Porte had to follow an inflationary policy to meet the army expenses. The emission financing of war has led to a steady increase in effective demand. With the war, an important part of the goods in the Ottoman market was allocated to the army. The share allocated to the consumption of the civilian population has gradually narrowed. The blockade of the country from the sea, the passing of the railway international lines through the enemy countries, the stockpiling of foodstuffs that the countries could export due to the war negatively affected the Ottoman foreign trade relations and daily compulsory consumption items fell into the black market in a short time (Toprak, 2003: p.101). 


\section{Economic Life in Rize Before the First World War}

After the Ottoman-Russian War of 1877-1878, also known as the 93 War, the borders of the Lazistan Sanjak changed and the center of the sanjak became Rize. Throughout history, Rize has not been a center of attraction due to its rugged geography and its remote location. However, commercial life has always existed, and this trade was mostly made from Rize pier at the beginning of the 20th century. The reason why trade was carried out from Rize pier is that there was almost no road at that time. In addition, the sea route has been faster and less costly than the land route. This is one of the reasons why land road construction was overlooked at that time. In addition, technology and infrastructure insufficiencies can be shown among the other reasons for road road inadequacies.

When the commercial life in Rize was examined at the beginning of the 20th century, the shops and stores in Rize, which also affected the commercial activity of the region, were generally located in the central districts of Rize such as Yeni Çarşı, Yukarı Çarşı and Aşağı Çarşı streets and Medrese-i Cedid Street or close to the seaside. The shops and stores in these places were built close to each other. In addition to private shops, there are also foundation shops. Moreover, there are shops and stores in some villages and neighborhoods far from the center. The coffee houses and bakeries mentioned below are mostly located in the port area of the neighborhoods (Pehlevan, 2008: p.59). At the beginning of the 20th century, there were nearly five hundred shops, 25 bakeries, 10 cook shops, 3 restaurants and 15 coffee houses in Rize (Emiroğlu, 2009: p.359). One of the social structures in Rize is the telegraph house. This telegraph house was built around the Rize Government Office in 1870. The land on which the telegraph house was built is the property of Tuzcuzâde Hacı Arif Ağa, one of the examiners of the Meclis-i De'âvî and was donated by him to cânib-i mirî. For the construction of the twofold telegraph house, 6726 kurus 10 money was spent (Pehlevan, 2008: p.57).

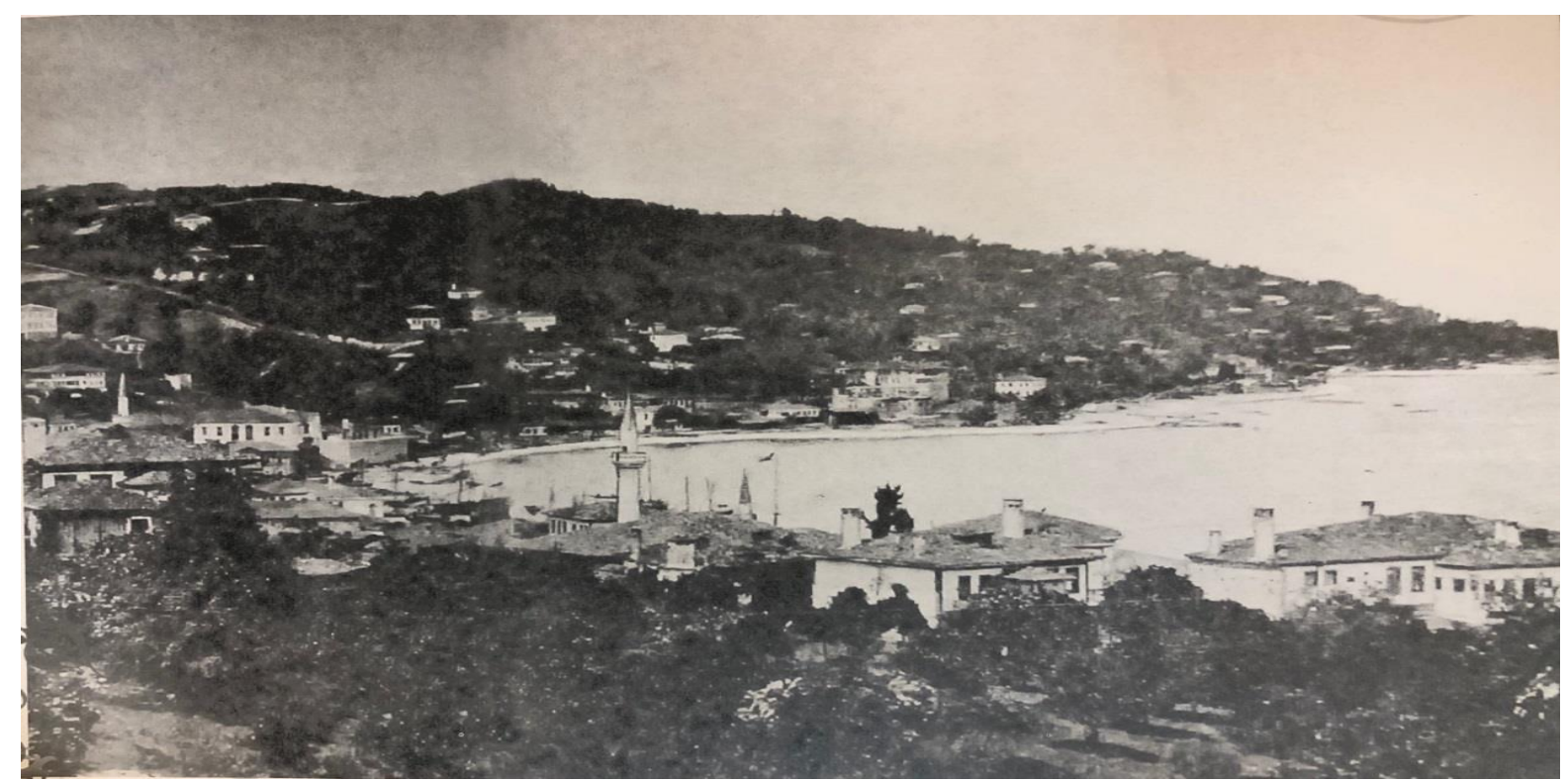

Figure 1: General View of Rize at the end of the 19th century

Source: Fatih Sultan Kar, Evvel Zaman İçinde Rize, İstanbul: Rize Vitrini Ajans, 2010, s.47. 
At the beginning of the 20th century, the population living in Rize district, which was the center of the Lazistan Sanjak, is 93,927. 92,934 of this population, including males and females, belong to the religion of Islam. The remaining 993 people are Greeks (Emiroğlu, 2008: p.549). When it comes to 1914, it is seen that 122,055 Muslims, 1507 Greek and 5 Armenians lived in Rize. The total population of Rize in 1914 was recorded as 123,567 (Karpat, 2010: p.378). It is observed that the population of Rize has increased by only 29,064 people after 12 years. This means that the population of Rize increased by an average of 2,047 people per year, based on the aforementioned years. The point that the very low population growth points out is the fact that Rize is not an economically and commercially attractive center.

In order to understand the truth about economic life, it is necessary to examine import and export data. Consul Satow reveals the goods imported by Rize just before the First World War in the Trabzon Province Trade Report in 1912 (Şaşmaz, 2014: p.1608-1609):

Table 1: Rize Import Data, 1912

\begin{tabular}{|l|l|l|}
\hline Products & $\begin{array}{l}\text { United } \\
\text { Kingdom } \\
\text { (f) }\end{array}$ & $\begin{array}{l}\text { Other } \\
\text { countries } \\
\text { (f) }\end{array}$ \\
\hline Candles & - & 310 \\
\hline Carpets and rugs & - & 420 \\
\hline $\begin{array}{l}\text { Chemicals and } \\
\text { drugs }\end{array}$ & 50 & 160 \\
\hline $\begin{array}{l}\text { Cotton products } \\
\text { and yarn }\end{array}$ & - & 23770 \\
\hline $\begin{array}{l}\text { Coffee } \\
\text { Pottery and } \\
\text { glassware }\end{array}$ & - & 360 \\
\hline Firearms & - & 300 \\
\hline Flour & - & 11620 \\
\hline $\begin{array}{l}\text { Fruits-vegetables- } \\
\text { nuts }\end{array}$ & - & 330 \\
\hline Hardware-iron & - & 2330 \\
\hline $\begin{array}{l}\text { Animal skin and } \\
\text { hide }\end{array}$ & - & 1620 \\
\hline Sewing machine & - & 110 \\
\hline Copper-zinc & 50 & 420 \\
\hline Olives and olive oil & - & 350 \\
\hline Oil & - & 5000 \\
\hline Rice & 2330 & 2760 \\
\hline
\end{tabular}

Source: Musa Şaşmaz, Cilt:3, p.1608.

\begin{tabular}{|l|l|l|}
\hline Products & $\begin{array}{l}\text { United } \\
\text { Kingdom (f) }\end{array}$ & $\begin{array}{l}\text { Other } \\
\text { countries } \\
\text { (f) }\end{array}$ \\
\hline $\begin{array}{l}\text { Sack-canvas- } \\
\text { linoleum }\end{array}$ & - & 160 \\
\hline Soap & - & 380 \\
\hline $\begin{array}{l}\text { Alcohol-wine- } \\
\text { beer }\end{array}$ & - & 150 \\
\hline Sugar & - & 5000 \\
\hline $\begin{array}{l}\text { Wheat-barley- } \\
\text { corn }\end{array}$ & - & 62300 \\
\hline Cement-lime & - & - \\
\hline Tobacco & - & 1300 \\
\hline $\begin{array}{l}\text { Wool product- } \\
\text { yarn }\end{array}$ & 6150 & 1600 \\
\hline Clock jewelery & - & 800 \\
\hline Paper & - & 120 \\
\hline Shoe rubber & - & 1200 \\
\hline Fez & - & 850 \\
\hline Match & - & 2100 \\
\hline Timber & - & 3200 \\
\hline Perfume & - & 8350 \\
\hline Other Products & - & \\
\hline
\end{tabular}

Source: Musa Şaşmaz, Cilt:3, p.1609. 
As can be seen from the table, more than thirty items of products are imported. Among these products, wheat, barley, corn, cotton products, yarn and flour take the lead. A large part of woolen products and yarns are imported from Britain. In addition, it is among the conclusions that can be drawn from the variety of imported goods that came to Rize in 1912 that almost all kinds of goods were needed in the starboard. Looking at the export data for the same year, in Rize, the center of the Lazistan Sanjak, the share of beans in exports is $f 1560$, pickled fish $f 280$, fruit and vegetable and hazelnuts $f 2120$, animal skins and hides $f 220$, domestic products $£ 11,240$, dolphin oil $320 £ 720$ for dried meat, $£ 40$ for beeswax, $£ 90$ for wool and mohair, and $f 1920$ for other products (Şaşmaz, 2014: p.1612). Rize cloth, also known as feretiko, is the most important commercial industrial product of the region, which has been subject to trade from ancient times to the present. The fact that the production of Indian cannabis (jute), which is the raw material of the Rize cloth, dates back to Rize and Trabzon regions, is a strong sign that the weaving in the region started long ago (Hut, 2012: p.9-10). This product has constituted one of the important livelihoods of the region and although it is not as important as it used to be, it still maintains its place among the traded products today. Among the woven products, Rize cloth stood out with its quality and price, and it was demanded not only from within the country but also from abroad (Keleş, 2013: p.45). When the import and export relationship is examined, it is seen that Rize is insufficient in producing and exporting products. It is not possible to explain this situation only with the economic world view of the Ottoman Empire. In addition to the fact that natural resources and geography do not allow the production, releasing or developing of products to be exported, the lack of technology also shows that Rize is experiencing an economically troublesome process. In other words, before the First World War, Rize can be defined as an Anatolian city that could continue its commercial life in its region, although it was not at a sufficient level in terms of economic life.

To summarize the economic life in Rize before the First World War, it is observed that tradesmen and civil servants were predominant in Rize. It is understood that commercial life is limited in Rize, which has an economic life dominated by tradesmen. In Rize, where it is understood that high-yield products cannot be produced, more fruit and vegetable production stand out, which leads to the conclusion that the export input for Rize is low. It is observed that import items are excessive in terms of meeting the needs of the people, and for this reason, the money in hand goes out of Rize. Despite all the limited commercial and economic life due to climate, geography and technological inadequacies, Rize is an economy that tries to be self-sufficient.

\section{Rize During the First World War}

Although the First World War started in 1914, Rize and its surrounding were included in the war only in 1915. The biggest enemy of the Ottoman State in the Lazistan Sanjak line was the Russian State. In February 1915, it was reported to the center that one of the two enemy 
Kalyoncuoğlu, K. S. (2021). Economic effects of the First World War on Rize.

Fiscaoeconomia, 5(2), 492-504. doi: 10.25295/fsecon.899773

warships from Batumi was on the Sarp coast and the other was bombarding Fındıklı ${ }^{3} \mathrm{BOA}^{4}$, DH.EUM. 2.Şb. 4/6, (3 Ra 1333/18 February 1915). The next day, as stated in the telegram of the Governor Cemal Azmi, the enemy ships that departed from Batumi before noon fired some positions between Fındıklı and Arhavi and returned in the direction of Hopa (BOA, DH.EUM. 2.Şb. 4/8, (4 Ra 1333/19 February 1915). On February 2, 1915, it is reported that two enemy fleets attacked the beaches of Rize, Of and Sürmene and damaged them (BOA, DH.EUM. 2.Şb. 4/61, (30 Ra 1333/15 February 1915). Two days later, a Russian torpedo damaged the Port of Athens (BOA, DH.EUM. 2. Şb. 4/67, (2 R 1333/17 February 1915). During this period, many Russian attacks took place, but there was no high-level loss in Rize and its surroundings until August 1915. It is observed that the attacks of the Russians increased in August. It is reported that a Russian torpedo from Batumi arrived in Of in the second half of August and damaged the two boats there, and then opened fire on the boats and bridges at the mouth of Kalapatamoz Creek in Rize and the boats in the surrounding piers (BOA, DH.EUM. 5.Şb. 16/45, (13 L 1933/24 August 1915). Again, at the end of August, the Russian torpedoes, whose number could not be determined, opened fire on the cutout at the Liparit ${ }^{5}$ pier in Rize. It was understood that this fire did not hit the cave but hit a house and destroyed a part of the house (BOA, DH.EUM. 5.Şb. 16/45, (20 L 1933/31 August 1915).

During this period, many conflicts took place in the lands occupied by the Russians, the people who escaped from the destructive effects of the war had to migrate from the region under the name of muhajir, and those who migrated faced many difficulties on the roads (Alşan, 2014: p.177). The people of sanjak, who were subjected to Russian occupation from March 1916 to February 1918, had a very difficult time. Due to the occupation, most of the people migrated to high places and unoccupied western parts, and they had to leave their homes. Citizens who rarely left their places were attacked by Greek and Armenian gangs (Demirci ve Saraç, 2012: p.211). In order to accelerate this migration, Russian agents in the region were making black propaganda (Tekir, 2016: p.54). The Russians did not seem to be willing to stop. First, Russian troops were landed near Pazar ${ }^{6}$. The last intense attacks of the Russian navy before the invasion of Rize took place in January and February of 1916. On January 19, a Russian torpedo was withdrawn by bombing the Venka pier near Mapavri ${ }^{7}$ after examining

\footnotetext{
${ }^{3}$ It is $60 \mathrm{~km}$ from Rize. The district, formerly known as Viçe, is surrounded by Arhavi in the east, Ardeşen in the west, Yusufeli in the south and the Black Sea in the north. Its area is $409 \mathrm{~km}^{2}$ and its population is 16,241 . See: Rize Provincial Directorate of Culture and Tourism, "Fındıklı", https://rize.ktb.gov.tr/TR-256716/findikli.html ${ }^{4} \mathrm{BOA}$ is the abbreviation form of Ottoman archives of the prime ministry, which will be stated as BOA in the further parts of this study.

${ }^{5}$ Its current name is Yalıköy.

${ }^{6}$ Pazar district remained connected to Batumi before Batumi was left to Russia, and in 1864 it was completely transformed into a district. It was occupied by the Russian in 1916 and survived from the Russian occupation in 1918. During the Republic period, the name Athena was changed to Pazar in 1928. Pazar was established in east west direction on Hopa - Rize state road in east of Rize. Ardeşen is located to the east, Çayeli to the west, Hemşin and Çamlıhemşin to the south, and the Black Sea to the north. See: Pazar Governorate, "Pazar's History", http://www.pazar.gov.tr/tarihce

${ }^{7}$ Mapavri, in $1461 \mathrm{II}$. After Mehmed (Fatih) annexed the Trabzon state to the Ottoman lands, he came under Turkish rule. For the next 50 years, Mapavri was the border point of the Ottoman Empire on the Black Sea coast. The region, which was under Russian occupation for two years during World War I, was again under Turkish rule on March 9, 1918. Mapavri became a district in 1878 with the name Çaybaşı in 1944. Later its name was changed to Çayeli. See: Çayeli Governorate, "History of Çayeli", http://www.cayeli.gov.tr/caveli-tarihi
} 
Kalyoncuoğlu, K. S. (2021). Economic effects of the First World War on Rize.

Fiscaoeconomia, 5(2), 492-504. doi: 10.25295/fsecon.899773

Rize Port with a projector (BOA, DH.EUM. 5.Şb. 20/52, (11 Ra 1334/17 January 1916). After 5 days, 18 pieces of warships belonging to the Russians attacked the town of Fındıklı. According to the information about the bombing and other activities carried out by the enemy navy on the beaches of Trabzon, Rize, Giresun and Görele, in September, Deputy Governor of Trabzon Fuat Bey wandered the shores of 4 enemy torpedoes in Lazistan Sanjak, Kukulat (ikiztepe) of Pazar and Samuran and bridge and Arkotil of Çayeli (BOA, DH.EUM. 5.Şb. 16/45, (27 L 1333/7 September 1915, p.2). It was reported from the Lazistan Sanjak that they partially destroyed a house, although they could not hit one cutaway in Rize's Liparit (Yalıköy) pier by firing up to 10 bullets (BOA, DH.EUM. 5.Şb. 16/45, (27 L 1333/7 September 1915, p.4). According to the information given to the Ministry of Internal Affairs, a torpedo from Batumi came to the coast of Of and destroyed 2 boats that had retreated to their shelters, and by firing 20-30 bullets to the boats at the mouth of Rize's Kalapatomoz River (Iyidere) and the bridge and the boats of the surrounding pier, and after the damage and they are gone (BOA, DH.EUM. 5.Şb. 16/45, (27 L 1333/7 September 1915, p.6). The Russians continued to increase their attacks towards the West from Kemalpaşa, Hopa and Arhavi and they occupied Arhavi on December 2, 1915 (Demirci ve Saraç, 209). In the sanjak, where there are many economic and social problems, serious damage occurred with the First World War and the existing negativities increased. The places severely damaged by the Russian bombardment in Lazistan in 1915 and the amount of damage are given below (Temel, 2009: p.136-137):

1. Damages on the beaches of Hopa District: $5,742,500$

2. Damages in households in Pazar, Ardeşen and Gora: 84,900

3. Damages in Pazar, Giresun, Kastel ${ }^{8}$, Limanköy and Zarha ${ }^{9}$ (Hisarlı) households: $2,160,200$

4. Damages incurred in Miladis, Pazar and Denek: 696,900

5. Damage in Rize Port: 475,409

6. House and belongings of Şevki Efendi in Bucak Village of Hopa: 75,000

There does not seem to be an almost undamaged place in the Sanjak of Lazistan. The effects of the damage caused long-term problems in many areas because the damage of any port or pier will prevent trade from this port or pier, it will cause the starboard to be dragged into more negative conditions economically. As it can be understood from above mentioned datas, the damage of the Lazistan Sanjak is over 7,000,000 kuruş ${ }^{10}$. This figure is a very serious amount for that period. After the Russians attacked Fındıklı on January 24, 1916, the Turkish troops retreated to Abu River and started to defend. In the clash that took place in this region for 6 days, the people of Fındıklı caused great damage to the Russians (Demirci ve Saraç, p.209). Atina was occupied on March 5, 1916, Çayeli on March 6, Rize on March 8 (Sarikaya, 2004: p.31-37). While the First World War was going on, the influence of the Russian Wars on the fronts decreased upon the Communist Revolution that started in Russia on March 9, 1917.

\footnotetext{
${ }^{8}$ It is a village about 3 miles beyond Sürmene. See: Sarı, İ. (2018), Sürmene: Yeşilliklerin gelin gibi süslediği güzel ilçe, Nokta e-kitap, p.62.

${ }^{9}$ It is a neighborhood of Zarha Sürmene. In the past, its name was changed to Hisarlı, today it is known as Orta Mahalle. See: Sarı, 2018: 73.

${ }^{10}$ In those years, the amount of pure silver contained in the Ottoman kuruş corresponds to 1 gram. See: Şevket Pamuk (1997), An Economic and Social History of the Ottoman Empire: 1300-1914, Volume 1, Cambridge:

Cambridge University Press, Table IVa.
} 
Kalyoncuoğlu, K. S. (2021). Economic effects of the First World War on Rize.

Fiscaoeconomia, 5(2), 492-504. doi: 10.25295/fsecon.899773

Therefore, the Russians were surrendering without much resistance in the Caucasian Front. However, the Russians had 250 thousand forces on this front supported by 470 cannons. Despite this, the Russians withdrew from the war with the Brest-Litovsk Treaty under various pretexts (ATASE, 1979: p.652). With the end of the Russian invasion in the Eastern Black Sea following the Erzincan Armistice signed in 1917, Rize was liberated from the enemy occupation on March 2, 1918 (Arslan and Usta, 2014: p.81).

After the Russian occupation was over, the emigrants, who had to leave their hometown during the war, started to return. The immigrants used the land and sea routes for their return. However, immigrants faced many problems on the way back. One of these problems is the money that the boatmen in Rize and Trabzon demand from the immigrants. Immigrants, who are already in a difficult situation, become more troubled due to this problem. Apart from this, it is also a problem that immigrants are not even served soup. These are among the notices sent to Trabzon Province (BOA, DH.ŞFR. 65/17, (11 L 1336/20 July 1918). It was also stated in the records that some of the refugees from Rize were traitors. What should be done to settle these traitors in Rize is also stated. It is especially emphasized that those who are found to be traitors should be helped (BOA, DH.ŞFR. 65/17, 14 N 1334/15 June 1916).

\section{Conclusion}

Rize, which is the center of the Lazistan Sanjak, appears to be a place that has not developed sufficiently economically. The reasons for this include the unsuitability of the land and the climate to grow different kinds of products, the location not being on the trade route, and the inadequacies of infrastructure and technology. Rize is trying to show the feature of being an economy that tries to be self-sufficient before the First World War. However, the high number of import items and the limited number of export items makes Rize a center with external deficit. Importing dozens of products including flour and timber, Rize exports products with low returns such as fruits and vegetables. Rize Cloth, on the other hand, can be shown as the high-yield export product of Rize.

Before the First World War, there were many shops in Rize. Tradesmen are predominantly prominent in the operation of economic life in Rize. Due to the insufficiency of the highway and the faster and cheaper sea route, the commercial goods were coming to Trabzon by sea, and from there they came to the Rize pier by sea again. It is observed that goods entry and exit to Rize are mainly made by sea.

The beginning of the First World War was almost a devastation for Rize, where the sea route was used very actively. The Russians started the operation from the Caucasus Front and attacked from the sea. At the beginning of 1915, Russians operating in the Black Sea made actual attacks on Rize. In addition to these attacks damaging many houses, workplaces and bridges, the economic life limited by the inability of the people of Rize to use the sea route has fallen into much more trouble. In other words, attacks suppress the economy in both directions. Due to the bombardments that started in September 1915, 5.742.500 kuruş was lost on the shores of Hopa and 484.900 kuruş in Athens, Gora and Ardeşen, and 475.409 kuruş in Rize Port (Öksüz ve Usta, 2006: p.393).

Another problem that arose with the occupation of the region by the Russians during the First World War is that the people had to migrate. With the occupation of Rize, the people of the 
region set out to migrate to the West or to high places. First of all, Trabzon was chosen as the center of the province, and later, as a result of Trabzon being exposed to the Russian threat, the immigration continued towards the west. Some of the people of the region, who had to leave their houses, preferred to stay, but they were attacked by Armenian and Greek gangs. In addition, due to the Russian control of sea routes, smuggling activities increased in the region when the financial difficulties increased (Kalyoncuoğlu, 2019: p.90-91). As a result, the First World War was a very difficult and depressing period for the people of Rize and the people of the region suffered the worst problem of this period.

\section{References}

Alkan, N. (2014, Kasım), “Alman Kaynaklarına Göre Osmanlı Devleti'nin Birinci Dünya Savaşı'na Girmesi”, Türkmen, Z. (Ed.), 1914'ten 2014'e 100'üncü Yılında Birinci Dünya Savaşı'nı Anlamak-Uluslararası Sempozyum, (p. 157-178), İstanbul: Harp Akademileri Komutanlığı Stratejik Araştırmalar Enstitiüsü.

Alşan, S. (2014), “Doğu Karadeniz'de Rus Çekilişi Sırasında Ermeni Faaliyetleri (1916-1918)”, Karadeniz incelemeleri Dergisi, 17 (17), 173-183.

Arslan, Z. \& Usta Y. (2014), "Rize'de Birinci Dünya Savaşı Yıllarında Rus Donanmasının Faaliyetleri ve Göçmenlerin Durumu (1915-1917)", Karadeniz incelemeleri Dergisi, 17 (17), 71-83.

Aybars, E. (2000), Türkiye Cumhuriyeti Tarihi 1, İzmir: Ercan Kitabevi.

BOA (Başbakanlık Osmanlı Arşivi), DH.EUM. (Dâhiliye Emniyet-i Umumiye Müdürlüğü), 2.Şb. 4/61, (30 Ra 1333/15 February 1915).

BOA, DH.EUM. 2.Şb. 4/6, (3 Ra 1333/18 February 1915).

BOA, DH.EUM. 2.Şb. 4/61, (30 Ra 1333/15 February 1915).

BOA, DH.EUM. 2.Şb. 4/67, (2 R 1333/17 February 1915).

BOA, DH.EUM. 2.Şb. 4/8, (4 Ra 1333/19 February 1915).

BOA, DH.EUM. 5.Şb. 16/45, (13 L 1933/24 August 1915).

BOA, DH.EUM. 5.Şb. 16/45, (20 L 1933/31 August 1915).

BOA, DH.EUM. 5.Şb. 16/45, (27 L 1333/7 September 1915).

BOA, DH.EUM. 5.Şb. 20/52, (11 Ra 1334/17 January 1916).

BOA, DH.ŞFR (Şifre Kalemi Belgeleri), 65/17, (14 N 1334/15 June 1916).

BOA, DH.ŞFR. 65/17, (11 L 1336/20 July 1918).

Çayeli Governorate, "History of Çayeli", http://www.cayeli.gov.tr/cayeli-tarihi.

Coşkun, A. "Cumhuriyetin Illk Yıllarında Türkiye Ekonomisi". Atatürkçü Düşünce Dergisi, Kasım 2003, (4), Sayfa: 72-77.

Demirci, S. \& Saraç, H. (2012), “XIX. Yüzyılda Trabzon Eyaleti’nin İdarî Birimi Olarak Atina/Pazar Kazâsı". SDÜ Fen Edebiyat Fakültesi Sosyal Bilimler Dergisi, (27), 1-14. 
Eldem, V. (1994), Harp ve Mütareke Yıllarında Osmanlı Imparatorluğu'nun Ekonomisi. Ankara: Türk Tarih Kurumu Yayınları.

Emiroğlu, K. (2008), Trabzon Vilayeti Salnamesi (1902), Cilt 20. Ankara: Trabzon illi ve iliçeleri Eğitim, Kültür ve Sosyal Yardımlaşma Vakfı Yayınları.

Emiroğlu, K. (2009), Trabzon Vilayeti Salnamesi (1904), Cilt 22. Ankara: Trabzon illi ve İlçeleri Eğitim, Kültür ve Sosyal Yardımlaşma Vakfı Yayınları.

Hut, D. (2012), “Doğu Karadeniz'de Geleneksel Dokumacılık: Rize Keten Bezi (feretiko) ve Sosyo-Ekonomik Etkileri", Rize Defteri 1, İstanbul: Dergah Yayınları.

Kalyoncuoğlu, K. S. (2019), “Lazistan Sancağı'nın Sosyo-Ekonomik Yapısı (1877-1918)”, Yüksek Lisans Tezi, Marmara Üniversitesi, SBE.

Kar, F. S. (2010), Evvel Zaman Iç̧inde Rize. İstanbul: Rize Vitrini Ajans.

Karpat, K. (2010), Osmanlı Nüfusu (1830-1914). Bahar Tırnakçı (çev.). İstanbul: Timaş Yayınları.

Keleş, S. (2013), “Osmanlı İmparatorluğu Döneminde Rize Ekonomisinde Dokumacılık”, Yüksek Lisans Tezi, Marmara Üniversitesi, SBE.

Küçük, C. \& Ertüzün, T. (1994). "Düyûn-ı Umûmiyye”, TDV İslam Ansiklopedisi içinde (Cilt 10, 58-62.) İstanbul: TDV İslâm Araştırmaları Merkezi.

Müderrisoğlu, A. (1990), Kurtuluş Savaşının Mali Kaynakları. Ankara: Türk Tarih Kurumu Yayınları.

Öksüz, H. \& Usta, V. (2014), “Birinci Dünya Savaşı Yıllarında Rus Donanması'nın Karadeniz Limanlarını Bombalaması”, Türkiyat Mecmuası, 24 (1), 25-51.

Özvar, E. (2003), Osmanlı Maliyesinde Malikane Uygulaması. İstanbul: Kitabevi Yayınları.

Pamuk, Ş. (1997), An Economic and Social History of the Ottoman Empire: 1300-1914, Volume 1, Cambridge: Cambridge University Press.

Pamuk, Ş. (2005), Osmanlı-Türkiye Iktisadî Tarihi 1500-1914, İstanbul: İletişim Yayınları.

Pazar Governorate, "Pazar's History", http://www.pazar.gov.tr/tarihce.

Pehlevan, A. (2008), “1495 Numaralı Şer'iyye Sicili Defteri ne Göre Rize'nin Ekonomik Ve Sosyal Hayatı". Yayınlanmamış Yüksek Lisans Tezi. Marmara Üniversitesi SBE.

Rize Provincial Directorate of Culture and Tourism, "Fındıklı", https://rize.ktb.gov.tr/TR256716/findikli.html

Sarı, ì. (2018), Sürmene: Yeşilliklerin gelin gibi süslediği güzel ilçe, Nokta e-kitap.

Sarıkaya, M. (2004), Milli Mücadele Döneminde Rize, Ankara: Atatürk Araştırma Merkezi.

Şaşmaz, M. (2014), Ingiliz Belgelerine Göre Trabzon Vilayeti Ticari Raporları 1830-1914, Cilt 3, Ankara: Türk Tarih Kurumu Basımevi.

T.C. Genelkurmay Askeri Tarih ve Stratejik Etüt Başkanlığı (1979), Birinci Dünya Harbinde Türk Harbi, 4 (1), Ankara: Genelkurmay Basımevi. 
Tabakoğlu, A. (1985), Gerileme Dönemine Girerken Osmanlı Maliyesi, İstanbul: Dergâh Yayınları.

Tekir, S. (2016), “Birinci Dünya Savaşı'nda Doğu Anadolu ve Doğu Karadeniz Rus İşgal Bölgelerinden Yapılan Göçler", Çağdaş Türkiye Tarihi Araştırmaları Dergisi, 19 (32), 4365.

Temel, M. (2009), “itilaf Devletleri'nin Osmanlı Kıyı Yerleşimlerine Yaptıkları Saldırılar ve Mütekabiliyet Esasına Göre Osmanlı Devleti'nin Aldığı Önlemler", Tarih Incelemeleri Dergisi, 24 (1), 117-150.

Toprak, Z. (2003), Ittihad-Terakki ve Cihan Harbi: Savaş Ekonomisi ve Türkiye'de Devletçilik 1914-1918. İstanbul: Homer Kitabevi.

Ethics Statement: The authors declare that ethical rules are followed in all preparation processes of this study. In case of detection of a contrary situation, Fiscaoeconomia has no responsibility and all responsibility belongs to the authors of the study.

Etik Beyanı: Bu çalışmanın tüm hazırlanma süreçlerinde etik kurallara uyulduğunu yazarlar beyan eder. Aksi bir durumun tespiti halinde Fiscaoeconomia Dergisinin hiçbir sorumluluğu olmayıp, tüm sorumluluk çalışmanın yazarlarına aittir. 